\title{
Ex vivo mRNA expression of toll-like receptors during latent tuberculosis infection
}

Birhan Alemnew ${ }^{1,2}$, Soren T. Hoff ${ }^{3}$, Tamrat Abebe ${ }^{4}$, Markos Abebe ${ }^{2}$, Abraham Aseffa $^{2}$, Rawleigh Howe ${ }^{2}$ and Liya Wassie 2* $^{*}$

\begin{abstract}
Background: Understanding immune mechanisms, particularly the role of innate immune markers during latent TB infection remains elusive. The main objective of this study was to evaluate mRNA gene expression patterns of tolllike receptors (TLRs) as correlates of immunity during latent TB infection and further infer their roles as potential diagnostic biomarkers.

Methods: Messenger RNA (mRNA) levels were analysed in a total of 64 samples collected from apparently healthy children and adolescents latently infected with tuberculosis $(n=32)$ or non-infected $(n=32)$. Relative expression in peripheral blood of selected genes encoding TLRs (TLR-1, TLR-2, TLR-4, TLR- 6 and TLR-9) was determined with a quantitative real-time polymerase chain reaction ( $q R T-P C R)$ using specific primers and florescent labelled probes and a comparative threshold cycle method to define fold change. Data were analysed using Graph-Pad Prism 7.01 for Windows and a $p$-value less than 0.05 was considered statistically significant.

Results: An increased mean fold change in the relative expression of TLR-2 and TLR- 6 mRNA was observed in LTBI groups relative to non-LTBI groups $(p<0.05)$, whereas a slight fold decrease was observed for TLR-1 gene.

Conclusions: An increased mRNA expression of TLR-2 and TLR- 6 was observed in latently infected individuals relative to those non-infected, possibly indicating the roles these biomarkers play in sustenance of the steady state interaction between the dormant TB bacilli and host immunity.
\end{abstract}

Keywords: TLR, mRNA, Latency, Tuberculosis, Children

\section{Introduction}

Mycobacterium tuberculosis (M. tuberculosis), a causative agent of tuberculosis, is responsible for death of nearly 1.2 million HIV-negative individuals globally [1]. Understanding the immune mechanism during latency, a state of persistent immune response to stimulation by M. tuberculosis antigens [2-4], has long been elusive for decades, while the global estimate shows just under a quarter $(\sim 23 \%)$ of the global population is labelled as

* Correspondence: liya.wassie@ahri.gov.et

${ }^{2}$ Armauer Hansen Research Institute, Addis Ababa, Ethiopia

Full list of author information is available at the end of the article latently infected [5]. The host innate immune response is the first line of defence against invading pathogens and is vital for the initial defence against $M$. tuberculosis and activation of the adaptive immune response [6]. Toll-like receptors (TLRs) are a class of proteins that are single, membrane-spanning receptors mostly expressed on leukocytes, including macrophages that have significant role in TB pathogenesis, one of the antigenprocessing cells and having a role during granuloma formation [7]. These receptors generally recognize structurally conserved molecules derived from microbes such as bacteria and viruses $[8,9]$ and mediate cell activation,

C C The Author(s). 2021 Open Access This article is licensed under a Creative Commons Attribution 4.0 International License, which permits use, sharing, adaptation, distribution and reproduction in any medium or format, as long as you give appropriate credit to the original author(s) and the source, provide a link to the Creative Commons licence, and indicate if changes were made. The images or other third party material in this article are included in the article's Creative Commons licence, unless indicated otherwise in a credit line to the material. If material is not included in the article's Creative Commons licence and your intended use is not permitted by statutory regulation or exceeds the permitted use, you will need to obtain permission directly from the copyright holder. To view a copy of this licence, visit http://creativecommons.org/licenses/by/4.0/. The Creative Commons Public Domain Dedication waiver (http://creativecommons.org/publicdomain/zero/1.0/) applies to the data made available in this article, unless otherwise stated in a credit line to the data. 
leading to induction of pro inflammatory cytokines, dendritic cell maturation and apoptosis $[8,10]$. Due to lack of long lasting immunity, little attention has been given to understanding the role of innate immunity in protection against latent TB [11]; however, this notion has now been changing with recent concepts of "trained immunity", where some of the main features and traits of the adaptive immunity, such as specificity and memory, are also shared by innate markers [12]. Identification of host biomarkers has long been a way forward in understanding the immunology of latent TB [6] and contributing to development of these tools is of immense importance. To this effect, we aimed to evaluate the expression of selected TLR mRNAs in peripheral blood as correlates of immunity during latent TB infection.

\section{Methods}

\section{Study setting}

Using purposive sampling, a total of 64 apparently healthy children and adolescents, aged between 11 and 18 years, and who have been recruited from different schools in Addis Ababa, capital city of Ethiopia (between 2014 and 2016), a country that has been reported as one of the highest TB burden settings globally [1], were included in this study. Children below the age of 11 were excluded for the sake of ethical regulations in Ethiopia, restricting blood volumes needed to conduct the proposed research. Participants had no known illness and were asymptomatic upon screening during enrolment and were categorized as latently infected with TB $(N=$ 32 ), after being tested positive by tuberculin skin testing (TST) or quantiferon (QFT) and non-infected $(N=32)$ after being tested negative by TST or QFT as previously described [13]. An indurations size of $10 \mathrm{~mm}$ and above was considered as a cut-off to define tuberculin reactivity [14]. Similarly, an IFN- $\gamma$ level above 0.35 International Units (IU)/mL for (TB Antigen-Nil) was considered as positive, while testing using QFT, according to the manufacturer's instruction. Participants had no known history of contact with a known TB patient or TB disease, with the majority having history of BCG vaccination and no concomitant infections (such as parasites) (Table 1). Diagnosis of stool helminthic parasites/ ova was done using the Kato-Katz technique as described in our previous study [13]. Participants who were HIV positive or those with a history of allergy or chronic infection at the time of clinical screening were excluded from the study.

\section{Analysis of mRNA expression using quantitative real-time PCR ( $q R T-P C R)$}

Approximately $2.5 \mathrm{ml}$ of venous blood was collected into PAXgene Blood RNA Kit (PreAnalytiX, QIAGEN); reverse transcribed into complementary DNA (cDNA) using Omniscript Reverse Transcription Kit (QIAGEN, Germany) and oligo (dT) primers (Promega, USA) as

Table 1 Socio-demographic and clinical characteristics of study participants $(N=64)$

\begin{tabular}{|c|c|c|c|c|}
\hline Variables & $\begin{array}{l}\text { Overall } \\
\mathrm{N}(\%)\end{array}$ & $\begin{array}{l}\text { LTBI group } \\
\mathrm{N}(\%)\end{array}$ & $\begin{array}{l}\text { Non-LTBI group } \\
\mathrm{N}(\%)\end{array}$ & $P$-value \\
\hline Sex & & & & 0.617 \\
\hline Male & $32(50)$ & $17(53.1)$ & $15(46.9)$ & \\
\hline Female & $32(50)$ & $15(46.9)$ & $17(53.2)$ & \\
\hline Age (Years) & & & & 0.802 \\
\hline $11-14$ & $32(50)$ & $16(50.0)$ & $16(50.0)$ & \\
\hline $15-18$ & $32(50)$ & $16(50.0)$ & $16(50.0)$ & \\
\hline BMI $\left(K g / M^{2}\right)^{a}$ & & & & 0.230 \\
\hline Underweight (< 18.5) & $33(51.56)$ & $18(56.2)$ & $20(62.5)$ & \\
\hline Normal (18.5-24.9) & $29(45.3)$ & $12(37.5)$ & $12(37.5)$ & \\
\hline Overweight (> 24.9) & $2(0.03)$ & $2(0.6)$ & $0(0.0)$ & \\
\hline BCG scar & & & & 0.118 \\
\hline Present & $33(51.6)$ & $13(40.6)$ & $20(62.5)$ & \\
\hline Absent & $25(39.1)$ & $15(46.9)$ & $10(31.2)$ & \\
\hline Indeterminate & $3(4.7)$ & $1(3.1)$ & $2(6.3)$ & \\
\hline Not recorded & $3(4.7)$ & $3(9.4)$ & $0(0.0)$ & \\
\hline Parasitic infections & & & & 0.026 \\
\hline Yes & $18(28.1)$ & $13(40.6)$ & $5(15.6)$ & \\
\hline No & $46(71.9)$ & $19(59.4)$ & $27(84.4)$ & \\
\hline
\end{tabular}

${ }^{\mathrm{a} B M I}$ body mass index and calculations were based on the Ethiopian demographic and health survey [15] 
described previously [13] and stored at $-20^{\circ} \mathrm{C}$ until assayed further by quantitative real-time PCR ( $q R T$ $P C R)$. To analyze the relative mRNA expression of selected TLRs in whole blood, $q R T-P C R$ was performed using QuantiTect Reverse Transcription PCR Kit (QIAG NE, Germany). The amount and purity of all cDNA samples were measured using NanoDrop 2000 Spectrophotometer (Thermo Scientific, Amersham Biosciences, UK), adjusted and normalized to a final concentration of $0.2 \mu \mathrm{g} / \mu \mathrm{l}$ and a total of $1 \mu \mathrm{g}$ of cDNA was used as a starting template in a total reaction volume of $12.5 \mu$ l. Specific primers and florescent-labelled probes (Eurofins MWG Operon) (Table 2) were used at a final concentration of $0.5 \mu \mathrm{M}$ and $0.3 \mu \mathrm{M}$, respectively to span exonintron junctions to prevent amplification of genomic DNA and amplicons of fewer than 150 base pairs to enhance the efficiency of PCR amplification. All the PCR mixtures were prepared using Corbett Robotics (Corbett Research, Australia) and run in duplicates including non-template controls using Rotor-Gene (RG-3000) thermo-cycler (Corbett Research, Australia). The $q R T$ $P C R$ cycling was carried out under the following conditions: initial Taq enzyme heat activation step at $95^{\circ} \mathrm{C}$ for $15 \mathrm{~min}$, followed by 40 repeats of three step cycling, denaturation step $94^{\circ} \mathrm{C}$ for $10 \mathrm{~s}$, primer/probe annealing step ranging between $58^{\circ} \mathrm{C}$ and $60^{\circ} \mathrm{C}$ for $20 \mathrm{~s}$ and final extension/polymerization step at $72^{\circ} \mathrm{C}$ for $30 \mathrm{~s}$. In all experiments, data were acquired at extension phase (on FAM/Sybr channel) and analyzed using Rotor-Gene
Real-Time Analysis Software 6.0 (Corbett Research, Australia). Human ribosomal protein ( $\mathrm{HuPO}$ ) was used as a housekeeping gene and internal control and a nontemplate tube as a negative control throughout the experiment; yielding a PCR efficiency of 97\% (See Supplementary data). The threshold cycle (CT), the PCR cycle at which the fluorescent signal of the reporter dye crosses an arbitrarily point, was set at the exponential phase of amplification and used as the quantitative endpoint of $q R T-P C R$ as described earlier [16]. Comparative CT method (also known as $2^{(-\Delta \Delta C T)}$ was used to describe the fold change in the relative expression of TLR genes as previously described [16]. Briefly, the non-LTBI group was considered as calibrator and the LTBI as target group to estimate the change in the $\mathrm{CT}$ values $(\Delta \mathrm{CT})$; all $\mathrm{CT}$ values were initially normalized to the $\mathrm{CT}$ values of $\mathrm{HuPO}$. The computed numbers indicate the fold change in the expression of a target gene in latently infected group relative to non-infected. A similar analysis was performed to compare the relative expression of the genes across age, where children under 15 years were considered as calibrator groups and adolescents (those 15 years and above) as target groups. Furthermore, to appreciate the relative expression of TLRs localized to the cell surface (TLR-1, TLR-2, TLR-4 and TLR-6) to enodsomal (TLR-9) regions, we compared the ratio of comparative CT values of TLRs in TST positive and negative groups. This work was conducted at the Armauer Hansen Research Institute (AHRI) laboratory.

Table 2 Primers and probes sequences ( $\left.5^{\prime}-3^{\prime}\right)$ used in this study

\begin{tabular}{|c|c|}
\hline Primers and probes & Sequence $\left(5^{\prime}-3^{\prime}\right)$ \\
\hline \multirow[t]{2}{*}{ HuPO Primer (5'-3') } & forward: GCT TCC TGG AGG GTG TCC \\
\hline & reverse: GGA CTC GTT TGT ACC CGT TG \\
\hline Probe (5'-6-FAM---TAMRA-3'): & TGC CAG TGT CTG TCT GCA GAT TGG \\
\hline \multirow[t]{2}{*}{ TLR-1 Primer $\left(5^{\prime}-3^{\prime}\right)$} & forward: CAG TGT CTG GTA CAC GCA TGG \\
\hline & reverse: TाT CAA AAA CCG TGT CTG TTA AGA G \\
\hline Probe (5'-6-FAM---TAMRA-3'): & TGC CCA TCC AAA ATT AGC CCG TTC C \\
\hline \multirow[t]{2}{*}{ TLR-2 Primer (5'-3') } & forward: GGC CAG CAA ATT ACC TGT GTG \\
\hline & reverse: AGG CGG ACA TCC TGA ACC T \\
\hline Probe (5'-6-FAM---TAMRA-3'): & TCC ATC CCA TGT GCG TGG CC \\
\hline \multirow[t]{2}{*}{ TLR-4 Primer (5'-3') } & forward: GAG CCT TाT CTG GAC TAT CAA G \\
\hline & reverse: TCC AAT GGG GAA GTT CTC TAG \\
\hline Probe (5'-6-FAM---TAMRA-3'): & AGA TIT GTC TCC ACA GCC ACC AGC \\
\hline \multirow[t]{2}{*}{ TLR-6 Primer (5'-3') } & forward: GAA GAA GAA CAA CCC TाT AGG ATA GC \\
\hline & reverse: AGG CAA ACA AAA TGG AAG CTT \\
\hline Probe (5'-6-FAM---TAMRA-3'): & TGC AAC ATC ATG ACC AAA GAC AAA GAA CCT \\
\hline \multirow[t]{2}{*}{ TLR-9 Primer ( $\left(5^{\prime}-3^{\prime}\right)$} & forward: GGA CC + T CTG GTA CTG CTT CCA \\
\hline & reverse: AAG CTC GTT GTA CAC CCA GTC T \\
\hline Probe (5'-6-FAM---TAMRA-3') & ACG ATG CCT TCG TGG TCT TCG ACA AA \\
\hline
\end{tabular}

HUPO human acidic ribosomal protein, TLR toll-like receptor, FAM 6-carboxyfluorescein, TAMRA tetramethylrhodamine 


\section{Data analyses}

Data from $q R T-P C R\left(2^{(-\Delta \Delta C T)}\right)$ were exported to GraphPad Prism Version 7.01 for Windows (GraphPad Software, La Jolla California USA, www.graphpad.com) and SPSS Version 20.0 for further statistical analyses. Categorical variables were presented as counts and percentages and compared using Chi square test. For two groups, analyses of the fold change in the relative expression of the TLRs were done using non-parametric ANOVA (Kruskal-Wallis test with Dunn's multiple comparison tests). In addition, Spearman linear correlation (r) was done to compare the correlation between the surface and intracellular TLRs. In all instances, a $P$-value $<0.05$ was considered statistically significant.

\section{Results}

Relative mRNA expressions of TLRs in LTBI and non-LTBI groups

The relative mRNA expressions of TLRs (TLR-1, TLR-2, TLR-4, TLR-6, and TLR-9), normalized to HuPO, were compared between latently infected and non-infected individuals. As the numerical value of the CT inversely relates to the amount of amplicon in the reaction [16], threshold values above 30 were considered as weak fluorescent signals. Results are presented as fold change of target gene expression in a target sample relative to a reference sample, normalized to a reference gene. With the relative gene expression set to 1 for the reference sample, the $\triangle \triangle C T$ is equal to 0 , resulting in $2^{0}$, i.e., 1 [17], and thus the mean fold change greater than one was considered as up-regulation or increased expression of a particular gene.

An increased mean fold change in the mRNA expression of TLRs was observed in latently infected individuals relative to those non-infected (Fig. 1). This increase was four-fold for TLR-2 gene (mean with SEM: 4.04, 0.91 and $95 \%$ CI $(2.18,5.91))$ and three-fold for TLR-6 (mean with SEM: 3.21, 1.12 and 95\% CI $(0.93,5.50)$ ) and approaching a two-fold increase for TLR-4 and TLR-9 (mean with SEM: $1.71 \pm 0.95$ and $95 \%$ CI $(0.2,3.7)$ and $1.59 \pm 0.8$ and $95 \% \mathrm{CI}(0.07,3.3))$, respectively $(p=$ 0.0001). On the other hand, a slight decrease in the mean fold change in the mRNA expression of TLR-1 was observed in those latently infected compared to non-infected (mean with SEM: 0.80, 0.29, and 95\% CI $(0.20,1.39)$ ) (Fig. 1a). The difference looks more apparent when the normalized $\Delta \Delta \mathrm{Ct}$ values are compared between LTBI infected and those non-infected (Fig. 1b).

\section{Relative mRNA expressions of TLRs among adolescents and children}

To understand whether adolescents have distinct mRNA expression patterns compared to younger children, the mean fold change in the expression of TLRs was also compared across age, where those aged between 11 and 14 years were considered as children and those above 15 years as adolescents and no significant difference was observed between the two groups (Data not shown). Similarly, no apparent difference was noted between male and female participants $(P>0.05)$ (Fig. 2).

\section{Visualizing TLR gene expression using heatmaps}

To better visualize the gene expression patterns among the study population, we did a heatmap using the $\Delta \Delta \mathrm{Ct}$ values of the TLR genes in LTBI and those non-infected (Fig. 3). This helps to clearly visualize the level of expressions of the genes in the study groups.

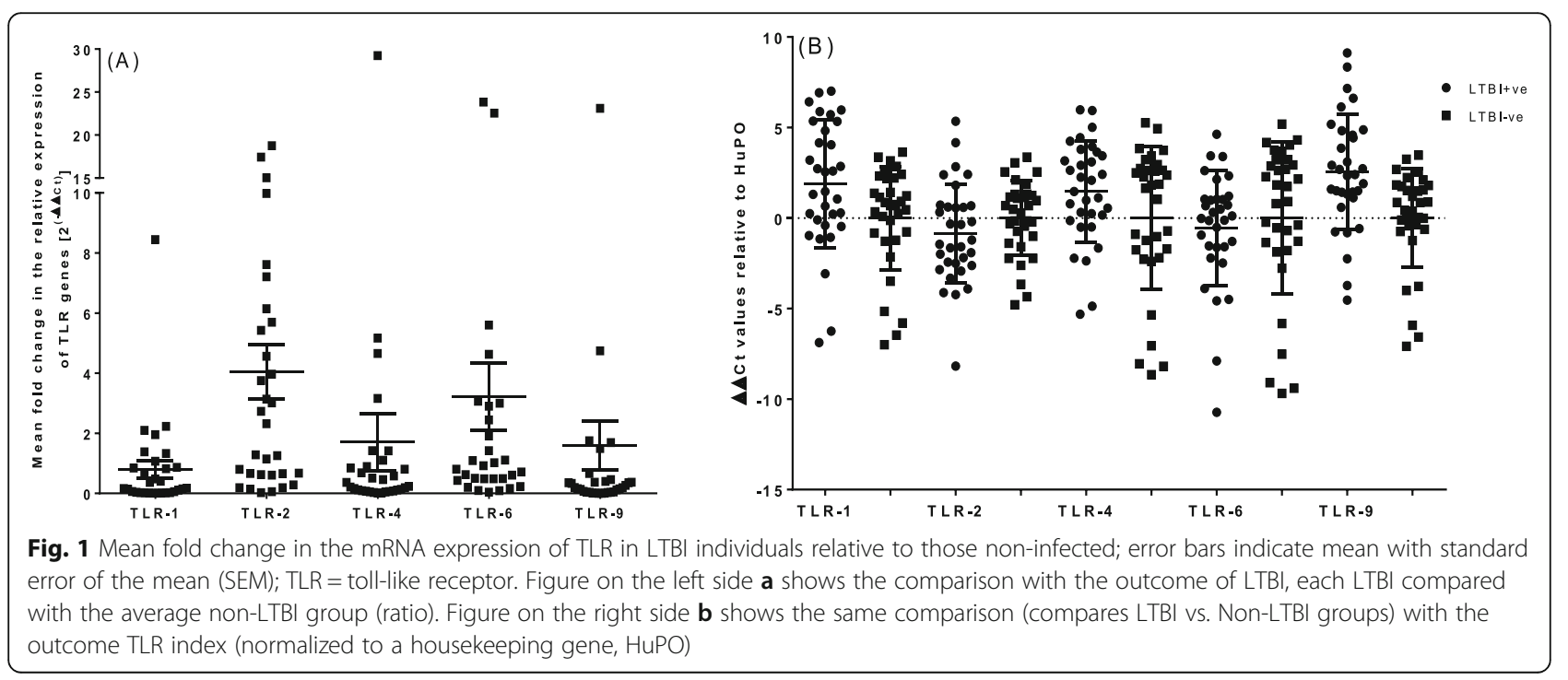




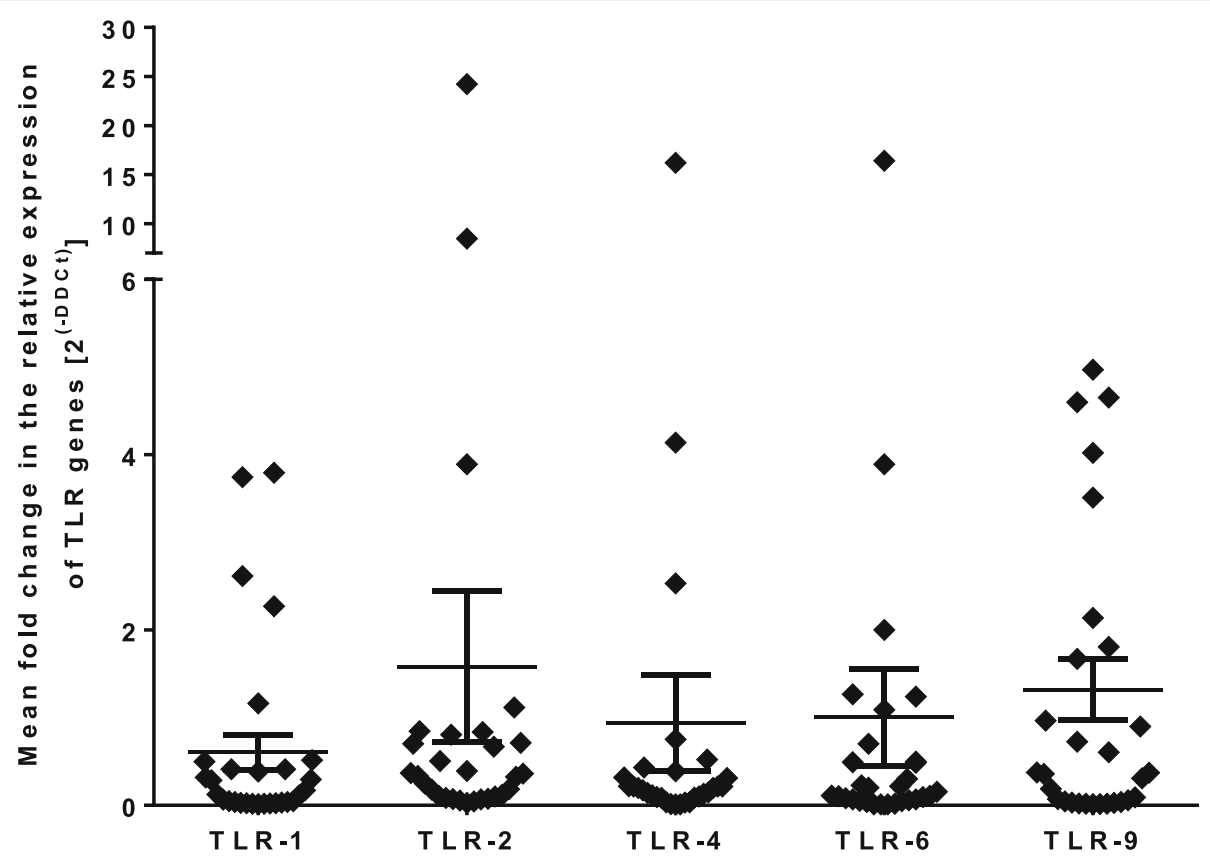

Fig. 2 Mean fold change in mRNA expression of TLRs among adolescents relative to children; error bars indicate mean values with standard error of the mean (SEM); TLR = toll-like receptor

\section{Correlation between expression of TLRs}

Similarly, correlation in the expression of surface TLRs with endogenously expressed markers was analysed and overall a positive correlation was observed between surface TLRs and an endogenously expressed TLR, TLR-9 (Fig. 4). A moderate correlation was also noted between the different surface TLRs $\left(r^{2}=0.6, P\right.$-value $<0.0001$, data not shown). A similar comparison was done for those high and low expressed receptors to see possible correlations, especially those forming heterodimers; and the ratios (TLR-2/TLR-1 and TLR-2/TLR-6) were found to be higher (7.2 \pm 1.12 (95\% CI: $4.9,9)$ and $3 \pm 0.6$ (95\% CI: 1.6, 4.2)), among latently infected group when compared to non-infected groups, respectively $(P=0.004)$ (Fig. 5).

\section{Discussion}

Early identification of individuals with LTBI, in particular those with a higher chance of progressing to a full blown active disease, is an important priority for $\mathrm{TB}$ control, especially in specific groups of population [18]. Currently there is no gold standard test for LTBI. Tools, currently existing to-date to fully control $\mathrm{TB}$, have remained to be inefficient and biomarkers have been considered as alternatives options. Recent studies have also demonstrated efforts to show improved tools to diagnose LTBI over existing immunodiagnostic tools such as the interferon gamma release assays (IGRA); one to mention, a novel IGRA assay, the LIOFeron TB/LTBI assay, that has proven to show a higher accuracy to diagnose MTB infection/TB disease compared to

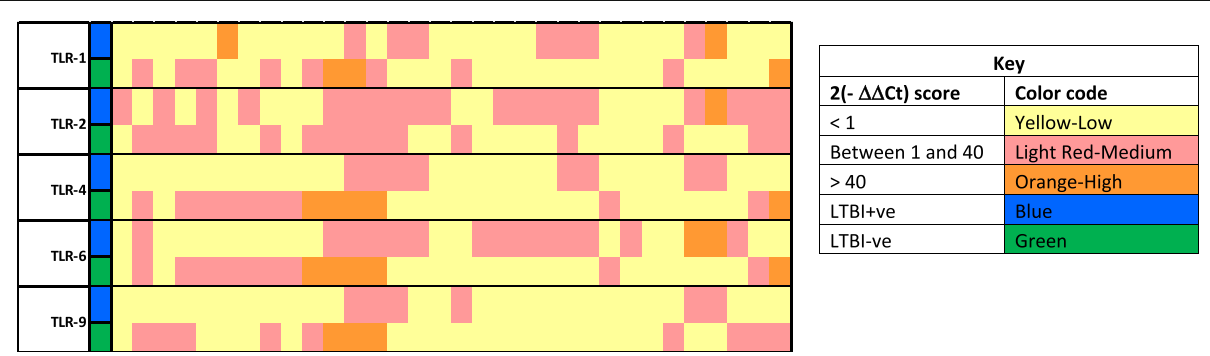

Fig. 3 Heatmap of the TLR genes among latently infected and non-infected individuals; Horizontal axis indicates $2^{(-\Delta \Delta C t)}$ values for TLR genes; score arbitrarily assigned taking 1 as a cut-off; colour codes indicate low, medium or high expression of the genes (Yellow indicates low, Light Red indicates medium and Orange indicates high expression); TLR = toll-like receptor 

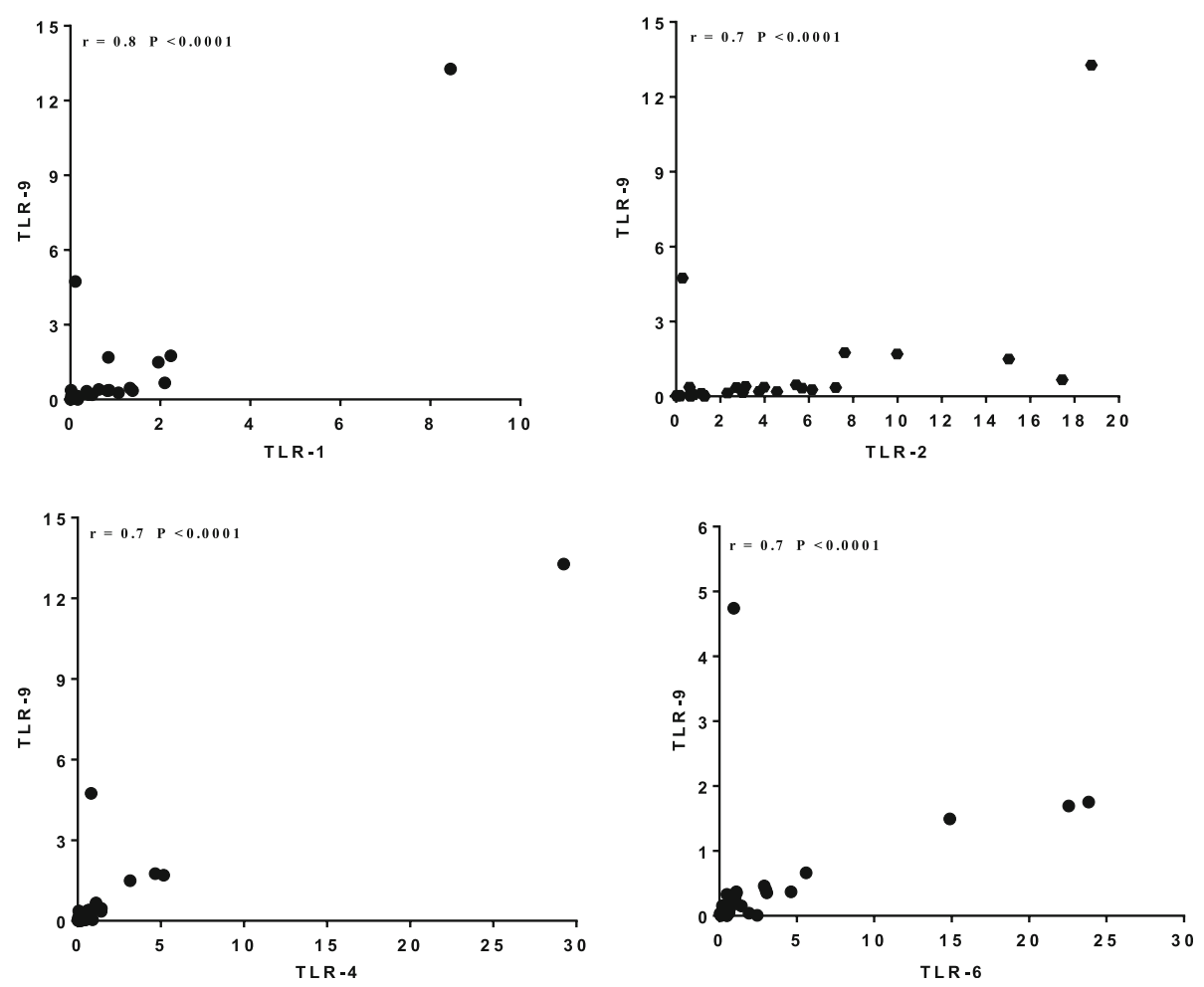

Fig. 4 Correlation between TLR markers expressed on cell surface and endosomal regions; Spearman correlation coefficient $(r=0.70$ and $P$-value $<0.0001$ ); data were normalized relative to $\mathrm{HuPO}$, the endogenous control; $\mathrm{TLR}=$ toll-like receptor

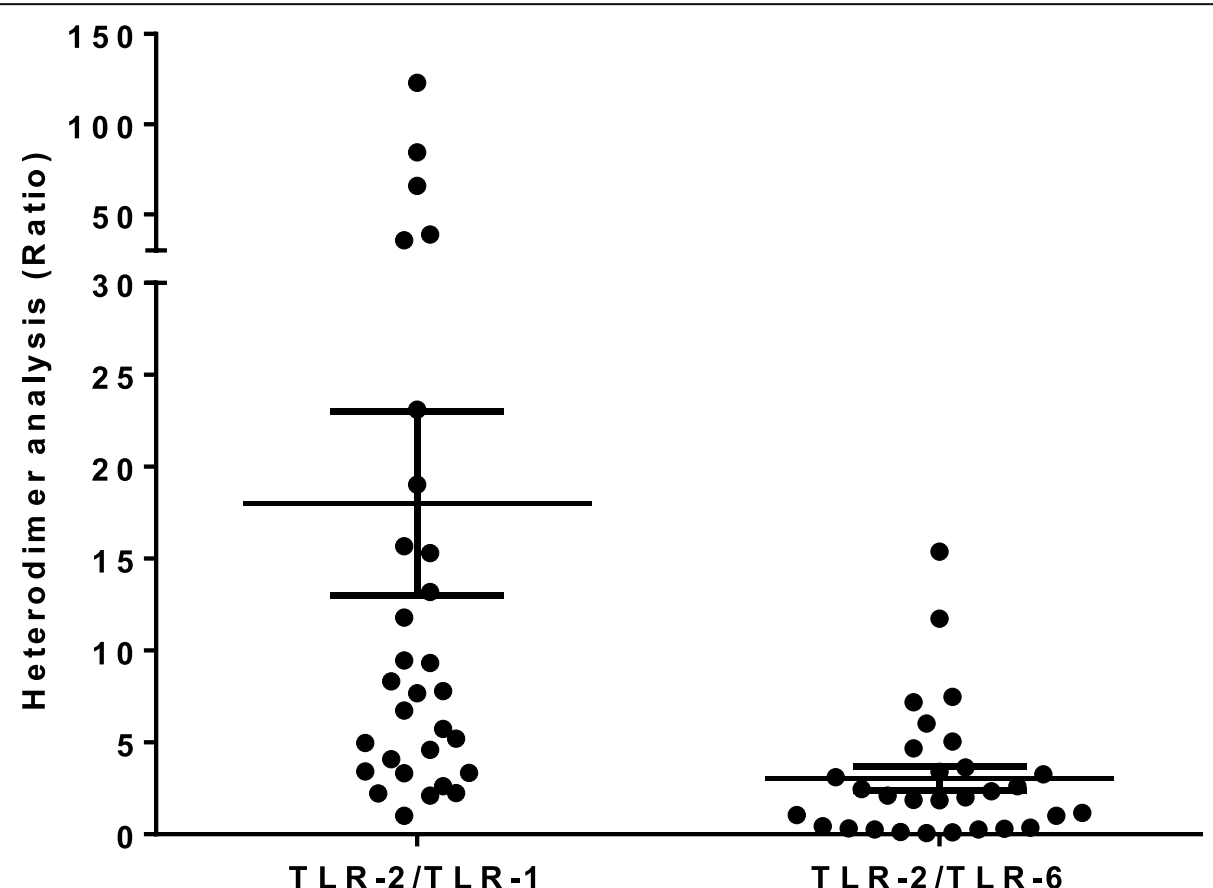

Fig. $\mathbf{5}$ Heterodimer mRNA expression, shown as ratios in LTBI group relative to non-LTBI group; data normalized to HuPO; error bars indicate mean \pm standard error of the mean (SEM); TLR = toll-like receptor 
QuantiFERON TB Gold Plus [19]. Nonetheless, despite extensive work to understand the role of adaptive immunity to $M$. tuberculosis, efforts to understand the role of innate immunity, particularly the fact that it can remember a previous exposure to TB via TLRs has become profound in recent years [20]. Toll-like receptors, one of the major innate immune markers, have been shown to be highly expressed during latent TB infection. These molecules are essential part of pattern-recognition receptor proteins expressed on the surface of the cell membrane or membrane of endocytic vesicles, having a role in the activation and triggering of pro-inflammatory cytokines, particularly in mycobacterial diseases [21]. The apparent increase in the relative expression of TLRs markers among latently infected individuals could be an indication for their role in the recognition of $M t b$ microbial components, such as lipoproteins, glycol-lipoprotein and lipomannan (LM) [22-25]. To mention few, the roles of TLR-1, TLR-2 and TLR- 6 have been reported in the recognition of triacylated lipopeptides and diacylated lipopeptides of $M t b$, TLR-4 in LPS recognition and TLR-9 homodimer in CPG DNA recognition [26]. In the present study, we observed an increased expression of TLR-2, TLR-4, TLR-6, and TLR-9 mRNA in latently infected group compared to non-infected, possibly indicating their role during latent $\mathrm{TB}$ infection through continuous stimulation and priming of immune system. Other studies have also reported a similar finding, although no significant difference in the expression of these markers was noted between active TB patients and latently infected individuals [27]. More studies have also indicated the occurrence of TLR stimulation that could result from interaction with circulating cytokines and modified by the cytokine milieu [27-29]. Although further confirmatory studies are warranted, our observation of enhanced expression possibly suggest a preliminary evidence for trained immunity, where MTB could potentially reside in and train the myeloid progenitor cells that will later be recognized by these receptors in the peripheral circulation. Studies have also demonstrated that MTB resides in hematopoietic stem cells, suggesting similar priming roles both in humans and animal models [30-34] and potentially leading to recognition of progenitors of the bacterial components by host TLRs in the blood circulation.

Toll-like receptor- 2 often forms heterodimers with either TLR-1 or TLR- 6 , interacting with diacylated and triacylated lipoproteins, respectively $[35,36]$, where heterodimers recognize mycobacterial cell wall glycolipids like lipoarabinomanna (LAM), LM and mycobacterial glycoprotein [37]. To this effect, we compared ratios between TLR- 2 and TLR-1 and TLR-6, where the ratios were significantly higher in latently-infected groups compared to those non-infected. The relative down regulation of TLR-1 gene in latently infected individuals could be related to the structural conformities required by TLR-1 to recognize microbial structures, as TLR-1 often needs TLR-2 to form a heterodimer to recognise microbial structures [26]. Similar observations were also reported by others, where the mRNA expression of TLR-1 was reduced in latently infected individuals [27].

Comparison of TLR expressions across age (between younger children and adolescents), however did not show any apparent difference. Since TLRs are mostly inborn immune receptors, expression of these markers across age may not be expected; however, exploring the expression of these genes across age may warrant further investigation with larger cohort to tease out immunological factors associated to higher incidences of TB infection among adolescents [13, 38-40] compared to younger children and further understand the significance of trained immunity.

Analysis of intra-compartment receptors (TLR-9) and surface receptors (TLR-1, TLR-2, TLR-4, and TLR-6), showed a strong positive correlation. Despite wide range of ligands recognized by TLRs, these receptors have been shown to share a common structural framework in their extracellular, ligand-binding domains, leading to cascaded pathways for pro-inflammatory cytokine signalling [24]. As a result, recognition of pathogen-associated patterns via TLRs direct the main pathways by which dendritic cells are activated and mature to provide signals to naive $\mathrm{T}$ cells and tailor specific immune responses [41]. Similar evidence demonstrated that TLR-2 heterodimer with TLR-1, TLR- 6 and TLR- 4 have been implicated as receptors involved in the recognition of mycobacterial antigens and activation of macrophages and dendritic cells [42]. On the other hand, synergic effects of polymorphisms between TLR-4 and TLR-9 has been shown to increase the risk of TB [25, 43]. In our study, a strong correlation was observed between expression of surface receptors and intracellular TLRs. Though each receptors can activate different components of the immune system, the synrgic effect and the activation of TLRs by their respective ligands has an informative role in directing acquired immunity $[9,10]$ and capable of modulating the adaptive immune response and differentiation of T cells [44, 45].

In conclusion, the present study demonstrated that upregulation of specific TLR markers, particularly TLR-2 and TLR- 6 during latency, possibly suggesting the role these markers play during latent TB infection to maintain the continuous priming of the immune system and monocytes emigrating into LTBI site in the lung and better able to sustain local immunity. Likewise, a strong correlation observed between endosomal receptors (like TLR-9) and surface TLRs during latency may show their role in maintaining the steady interaction between the 
dormant TB bacilli and host immunity. One could possibly argue an association between two variables (such as in this case between LTBI and TLR expression) in a cross-sectional study can simply imply cause-effect, while each variable could be casually related to a third or different underlying factor(s). Given that inflammatory biomarkers are normally distributed in a population, some individuals may always have higher biomarker levels than others, due to a number of usually unexplained reasons, some of which could also be associated with trained immunity or otherwise. It is also possible that associated underlying heightened immune mechanisms could simply contribute to increased ease to detect LTBI in one of two populations even though the true prevalence of latent TB in each population could be identical. Therefore, to further validate such observations designing studies in controlled groups such as before and after isoniazid therapy and also exploring the priming effect of MTB in milieu of myeloid progenitor cells is strongly warranted. In addition, exploring these and additional innate immune markers in a wider cohort of participants that also includes TB patients is warranted to elucidate whether these genes can be used as possible biomarkers in future booster TB vaccine trials.

\section{Supplementary Information}

The online version contains supplementary material available at https://doi. org/10.1186/s12865-021-00400-4

\section{Additional file 1.}

\section{Acknowledgments}

The authors are grateful to the study participants, their parents, participating schools, study nurses (Alemayehu Kifle, Bamlak Tesema and Haregewoin Yeshitela) and lab technicians (Azeb Tarekegne and Nahom Getachew) from AHRI.

\section{Declaration of preprint post of the MS}

The preprint of this article has been posted on Authorea server and can be accessed at https://doi.org/10.22541/au.160318269.96610728/v1

\section{Authors' contributions}

BA did the laboratory work, analyzed data and wrote the 1st draft of the manuscript; TA analyzed the data, wrote the manuscript and supervised the work; STH, MA, AA, RH and LW conceived the study design, analyzed the data, supervised the study and wrote the manuscript. All authors approved the final version of the manuscript.

\section{Funding}

This work was supported by EDCTP grant through the Collaboration and Integration of Tuberculosis Vaccine Trials in Europe and Africa (TBTEA) Consortium [grant number MS.2010.18000.002] and core funds from Armauer Hansen Research Institute (AHRI), received from SIDA and NORAD. The funders had no role in the study design, data collection and analysis, decision to publish, or preparation of the manuscript.

\section{Availability of data and materials}

The datasets generated and/or analysed during the current study are still under use for an on-going study and will be available from the corresponding author on reasonable request.

\section{Ethics approval and consent to participate}

The study was performed in accordance with the Declaration of Helsinki and approved by the AHRI/ALERT Ethics Review Committee (Ref. No. PO18/12), Addis Ababa University, College of Health Sciences, Ethics Review Committee (Ref. No. DRERC/005/09) and the National Research Ethics Review Committee (Ref. No. 3.10/811/05). Written informed and parental consent was sought for all participants and those aged below 18 years, respectively. Additionally child assent was sought for those aged between 15 and 17 years as per the Ethiopian IRB guidelines.

Consent for publication

Not applicable.

\section{Competing interests}

All authors declare no potential conflicts of interest. STH is currently a full time employee of Novo Nordisk a/s.

\section{Author details}

${ }^{1}$ College of Health Sciences, Department of Medical Laboratory Sciences, Woldia University, Woldia, Ethiopia. ${ }^{2}$ Armauer Hansen Research Institute, Addis Ababa, Ethiopia. ${ }^{3}$ Statens Serum Institute, Copenhagen, Denmark. ${ }^{4}$ Department of Microbiology, Immunology and Parasitology, College of Health Sciences, School of Medicine, Addis Ababa University, Addis Ababa, Ethiopia.

Received: 20 October 2020 Accepted: 14 January 2021

Published online: 28 January 2021

\section{References}

1. World Health Organization. Global tuberculosis report 2018. Geneva: World Health Organization, 2018

2. Gideon HP, Flynn JL. Latent tuberculosis: what the host "sees"? Immunol Res. 2011;50(2-3):202-12.

3. Chaves AS, Rodrigues MF, Mattos AM, Teixeira HC. Challenging mycobacterium tuberculosis dormancy mechanisms and their immunodiagnostic potential. Braz J Infect Dis. 2015;19(6):636-42.

4. Narasimhan P, Wood J, Macintyre CR, Mathai D. Risk factors for tuberculosis. Pulm Med. 2013;2013:828939.

5. Houben RM, Dodd PJ. The global burden of latent tuberculosis infection: a re-estimation using mathematical modelling. PLoS Med. 2016;13(10): e1002152.

6. Walzl G, Ronacher K, Hanekom W, Scriba TJ, Zumla A. Immunological biomarkers of tuberculosis. Nat Rev Immunol. 2011;11(5):343-54.

7. Kleinnijenhuis J, van Crevel R, Netea MG. Trained immunity: consequences for the heterologous effects of BCG vaccination. Trans R Soc Trop Med Hyg. 2015:109(1):29-35

8. Yanez A, Hassanzadeh-Kiabi N, Ng MY, Megias J, Subramanian A, Liu GY, et al. Detection of a TLR2 agonist by hematopoietic stem and progenitor cells impacts the function of the macrophages they produce. Eur J Immunol. 2013:43(8):2114-25.

9. Dowling JK, Mansell A. Toll-like receptors: the swiss army knife of immunity and vaccine development. Clin Transl Immunol. 2016;5(5):e85.

10. Skevaki C, Pararas M, Kostelidou K, Tsakris A, Routsias JG. Single nucleotide polymorphisms of toll-like receptors and susceptibility to infectious diseases. Clin Exp Immunol. 2015;180(2):165-77.

11. Dorhoi A, Kaufmann SH. Pathology and immune reactivity: understanding multidimensionality in pulmonary tuberculosis. Semin Immunopathol. 2016; 38(2):153-66.

12. Topfer $E$, Boraschi D, Italiani P. Innate immune memory: the latest frontier of adjuvanticity. J Immunol Res. 2015;2015:478408.

13. Wassie L, Aseffa A, Abebe M, Gebeyehu MZ, Zewdie M, Mihret A, et al. Parasitic infection may be associated with discordant responses to QuantiFERON and tuberculin skin test in apparently healthy children and adolescents in a tuberculosis endemic setting, Ethiopia. BMC infect Dis. 2013;13:265

14. American Thoracic Society. Targeted tuberculin testing and treatment of latent tuberculosis infection. MMWR Morb Mort Wkly Rep. 2000;49(RR-6):151.

15. EDHS. Ethiopia Demographic and Health Survey 2016. 2016. 
16. Livak KJ, Schmittgen TD. Analysis of relative gene expression data using real-time quantitative PCR and the 2(-Delta Delta C(T)) method. Methods. 2001;25(4):402-8.

17. Rao X, Huang X, Zhou Z, Lin X. An improvement of the $2^{\wedge}(-$ delta delta CT) method for quantitative real-time polymerase chain reaction data analysis. Biostat Bioinforma Biomath. 2013;3(3):71-85.

18. Zellweger JP, Sotgiu G, Corradi M, Durando P. The diagnosis of latent tuberculosis infection (LTBI): currently available tests, future developments, and perspectives to eliminate tuberculosis (TB). Med Lav. 2020;111(3):17083.

19. Della Bella C, Spinicci M, Alnwaisri HFM, Bartalesi F, Tapinassi S, Mencarini J, et al. LIOFeron(R)TB/LTBI: a novel and reliable test for LTBI and tuberculosis. Int J Infect Dis. 2020;91:177-81.

20. Lerm M, Netea MG. Trained immunity: a new avenue for tuberculosis vaccine development. J Intern Med. 2016;279(4):337-46.

21. Azad AK, Sadee W, Schlesinger LS. Innate immune gene polymorphisms in tuberculosis. Infect Immun. 2012;80(10):3343-59.

22. Thada S, Valluri VL, Gaddam SL. Influence of toll-like receptor gene polymorphisms to tuberculosis susceptibility in humans. Scand J Immunol. 2013;78(3):221-9.

23. Wu L, Hu Y, Li D, Jiang $W, X u B$. Screening toll-like receptor markers to predict latent tuberculosis infection and subsequent tuberculosis disease in a Chinese population. BMC Med Genet. 2015;16:19.

24. Biyikli OO, Baysak A, Ece G, Oz AT, Ozhan MH, Berdeli A. Role of toll-like receptors in tuberculosis infection. Jundishapur J Microbiol. 2016;9(10): e20224

25. Faridgohar $M$, Nikoueinejad $H$. New findings of toll-like receptors involved in mycobacterium tuberculosis infection. Pathog Glob Health. 2017;111(5): 256-64.

26. Zhao L, Liu K, Kong X, Tao Z, Wang Y, Liu Y. Association of polymorphisms in toll-like receptors 4 and 9 with risk of pulmonary tuberculosis: a metaanalysis. Med Sci Monit. 2015;21:1097-106.

27. Constantoulakis P, Filiou E, Rovina N, Chras G, Hamhougia A, Karabela S, et al. In vivo expression of innate immunity markers in patients with mycobacterium tuberculosis infection. BMC Infect Dis. 2010;10:243.

28. Bryson BD, Rosebrock TR, Tafesse FG, Itoh CY, Nibasumba A, Babunovic GH, et al. Heterogeneous GM-CSF signaling in macrophages is associated with control of mycobacterium tuberculosis. Nat Commun. 2019:10(1):2329.

29. Romieu-Mourez R, Francois M, Boivin MN, Bouchentouf M, Spaner DE, Galipeau J. Cytokine modulation of TLR expression and activation in mesenchymal stromal cells leads to a proinflammatory phenotype. J Immunol. 2009;182(12):7963-73.

30. Das B, Kashino SS, Pulu I, Kalita D, Swami V, Yeger H, et al. CD271(+) bone marrow mesenchymal stem cells may provide a niche for dormant Mycobacterium tuberculosis. Sci Transl Med. 2013;5(170):170ra13.

31. Tornack J, Reece ST, Bauer WM, Vogelzang A, Bandermann S, Zedler U, et al. Human and mouse hematopoietic stem cells are a depot for dormant mycobacterium tuberculosis. PLoS One. 2017;12(1):e0169119.

32. Mayito J, Andia I, Belay M, Jolliffe DA, Kateete DP, Reece ST, et al. Anatomic and cellular niches for mycobacterium tuberculosis in latent tuberculosis infection. J Infect Dis. 2019;219(5):685-94.

33. Jain $N$, Kalam H, Singh L, Sharma V, Kedia S, Das P, et al. Mesenchymal stem cells offer a drug-tolerant and immune-privileged niche to mycobacterium tuberculosis. Nat Commun. 2020;11(1):3062.

34. Fatima S, Kamble SS, Dwivedi VP, Bhattacharya D, Kumar S, Ranganathan A, et al. Mycobacterium tuberculosis programs mesenchymal stem cells to establish dormancy and persistence. J Clin Invest. 2020;130(2):655-61.

35. Farrugia M, Baron B. The role of toll-like receptors in autoimmune diseases through failure of the self-recognition mechanism. Int J Inflam. 2017;2017: 8391230.

36. Feng $Y$, Yang $S, M a ~ Y$, Bai $X Y$, Chen $X$. Role of toll-like receptors in diabetic renal lesions in a miniature pig model. Sci Adv. 2015;1(5):e1400183.

37. Harding CV, Boom WH. Regulation of antigen presentation by mycobacterium tuberculosis: a role for toll-like receptors. Nat Rev Microbiol. 2010;8(4):296-307.

38. Mahomed H, Hawkridge T, Verver S, Geiter L, Hatherill M, Abrahams DA, et al. Predictive factors for latent tuberculosis infection among adolescents in a high-burden area in South Africa. Int J Tuberc Lung Dis. 2011;15(3):3316.

39. Middelkoop K, Bekker LG, Liang $H$, Aquino LD, Sebastian E, Myer L, et al. Force of tuberculosis infection among adolescents in a high HIV and TB prevalence community: a cross-sectional observation study. BMC Infect Dis. 2011;11:156.

40. Ncayiyana JR, Bassett J, West N, Westreich D, Musenge E, Emch M, et al. Prevalence of latent tuberculosis infection and predictive factors in an urban informal settlement in Johannesburg, South Africa: a cross-sectional study. BMC Infect Dis. 2016;16(1):661.

41. Zhu J, Yamane H, Paul WE. Differentiation of effector CD4 T cell populations $\left.{ }^{*}\right)$. Annu Rev Immunol. 2010;28:445-89.

42. Takeda K, Akira S. Toll-like receptors in innate immunity. Int Immunol. 2005; 17(1):1-14.

43. Jahantigh D, Salimi S, Alavi-Naini R, Emamdadi A, Owaysee Osquee H, Farajian MF. Association between TLR4 and TLR9 gene polymorphisms with development of pulmonary tuberculosis in Zahedan, southeastern Iran. Sci World J. 2013;2013:534053.

44. Ma MJ, Xie LP, Wu SC, Tang F, Li H, Zhang ZS, et al. Toll-like receptors, tumor necrosis factor-alpha, and interleukin-10 gene polymorphisms in risk of pulmonary tuberculosis and disease severity. Hum Immunol. 2010;71(10): 1005-10.

45. Krutzik SR, Modlin RL. The role of toll-like receptors in combating mycobacteria. Semin Immunol. 2004;16(1):35-41.

\section{Publisher's Note}

Springer Nature remains neutral with regard to jurisdictional claims in published maps and institutional affiliations.
Ready to submit your research? Choose BMC and benefit from:

- fast, convenient online submission

- thorough peer review by experienced researchers in your field

- rapid publication on acceptance

- support for research data, including large and complex data types

- gold Open Access which fosters wider collaboration and increased citations

- maximum visibility for your research: over $100 \mathrm{M}$ website views per year

At $\mathrm{BMC}$, research is always in progress.

Learn more biomedcentral.com/submissions 